\title{
The Approaching Lease Accounting Regulations and Its Impact on Cost of Capital, "A Practical Case Study"
}

\author{
Shahir El-qawaqneh (Corresponding author) \\ Faculty of Economics \&Muamalat \\ University Sains Islam Malaysia, Malaysia,71800 \\ Tel: 60-16-796-301 E-mail: selkawakneh@gmail.com \\ Dr. NurHidayahBintiLaili \\ Faculty of Economics \&Muamalat, \\ University Sains Islam Malaysia, Malaysia,71800 \\ Tel: 60-12-233-1203E-mail: hidayah@usim.edu.my \\ DrKhairil F. Bin Khairi \\ Faculty of Economics \& Muamalat \\ University Sains Islam Malaysia, Malaysia,71800 \\ Tel: 60-17-260-1814E-mail: khairil@usim.edu.my
}

Received: Oct.27, 2015 Accepted: Nov23, 2015 Published: December 1, 2015

doi:10.5296/ajfa.v7i2.8493 URL: http://dx.doi.org/10.5296/ajfa.v7i2.8493

\begin{abstract}
We examine how the approaching international lease accounting regulations influence credit rating of particular airfreight company, we capitalize all of still effective operation lease agreements commencing in 2002 and expired on 2026. In particular we use actual operation lease data, not only the disclosed with off-balance sheet. Our results suggest that, on average, capitalization of over 12 months term operation leases, dramatically alter capital structure. Results either reports a positive impact on weighted average cost of capital WACC, credit rating is a financial risk assessment measurement used by credit holders, investors, and analysis, our results is consistent with the lease accounting standard sitters point of view;
\end{abstract}




\section{Macrothink}

Asian Journal of Finance \& Accounting ISSN 1946-052X 2015, Vol. 7, No. 2

investors and credit holders have the right to obtain a full transparent picture about firms lease activities in benefit of all parties. We also find some evidence that the positive change in WACC is related to the increasing portion of capitalized lease liability accompanied with an escalating decreeing in conventional debt, in certain conditions, this result suggests that financial lease has the advantage over conventional debt.

Keywords:lease accounting reform, capitalization, financial risk, cost of capital, credit rating 


\section{Introduction}

The relationship between contractual hidden obligations such like operating leases and equity risk has been an issue of attention for long time. Higher of equity capital return and higher of debt return may be required by investors and lenders to compensate for unrecorded liabilities and uncompleted or hidden information. A new lease accounting model is expected within the end of 2015, the new upcoming regulations came with a notion of lease information transparency. Investors, lenders, and analysis have the right to get complete transparent information about firms lease activities, therefore the new upcoming lease accounting regulations committed lessees to capitalize all above 12 months term uncancellable lease obligations.

Lessors and lessees should report useful information about the cash flows arising from leasing contracts, more transparency on leverage financing would enhance comparability. Han Hoogervorst, the chairman of IASB, and Leslie Seidman, the chairman of FASB stressed that developing of an improved lease accounting standard is vital, investors have the right to determine the hidden leverage from leasing, the proposed lease accounting standard is to address the inadequacies of current lease accounting Heffes (2013).Lease accounting reform would manipulate all financial statements, and consequently stir investors to consider operation lease capitalization's impact on their risk assessment. In particular, lender should consider the lease accounting's new rules in their lessees' credit worthiness assessments while the credibility analysts should also consider the change.

This research paper is an extension of prior work, it contribute to the ongoing international debate concerning the approaching proposed lease accounting standard and its economic consequences, it is recommended byHan (2010) and de Villiers and Middelberg (2013). De Villires recommended a case study research design that could be used to ensure a more accurate estimation of operating lease capitalization impact on a specific company, asmall sample will ensure that the lease contracts could be investigated on a lease-by lease basis in order to determine the exact remaining lease term, remaining minimum lease payments, and any other items that should be included in the calculation of the present value of the lease payments. Han (2010) recommended a research design that investigates the exact cost of debt in association with equity capital to outline more wide-ranging representation of the overall impact of the operation leases.

Secondly, to our knowledge, no previous studies have empirically documented evidence on lease accounting reform impacts on Jordan airfreight sector cost of capital, either, no previous study has imperially simulated real operational lease contracts capitalization on lease-by-lease bases.Therefore, in order to answer the question of "how could the upcoming lease accounting regulations influence airfreight firms cost of capital which heavily depend on operational lease? In a forward looking approach, we examine the financial structure of a company with $90 \%$ operational leased fleet.Weapply the upcoming lease accounting regulations to the Royal Jordanian Airlines financial statements over the period (2002-2014).we capitalize thirty real operational lease contracts on lease-by-lease bases. The remainder of this paper is organized as follows: Section 2 is a prior research review. Section 3 discusses methodology and data. Empirical analysis and results in section 3.Conclusion in 
section 4.

\section{Previous research}

Four studies have specifically examined whether operating lease obligations are included in the market assessment of equity risk (Beattie, Goodacre, \& Thomson, 2000a,2000b; Ely, 1995); Imhoff Jr, Lipe, and Wright (1993). In the first study, Imhoff Jr et al. (1993) extended their research by examining the airline and grocery industries. In the study, a sample of 52 grocers and 29 airlines with data available range from 1984-1990 were selected. They found that the total debt increased by $40 \%$ with regard to the median recognized liabilities for both industries. Further, they confirmed that the reported level of debt was associated with equity risk (measured as the standard deviation in stock returns). Having replicated this basic result then added a variable for the present value of operating leases, they found that it further explain the variation in equity risk. Interestingly, the magnitudes of the effects on equity risk were similar for both debt and operating leases. This result suggests again that leases (operating leases) behave like debt in their effect on equity risk.

Theories in finance and accounting provide linkage between lease and the cost of equity. Modigliani and Miller (1958, as cited in (Han, 2010) added the cost of equity capital as an increasing function of financial leverage where, if the unrecognized obligation from operating lease is treated as on-balance sheet debt, it should consequently increase the cost of equity Han (2010). Practically, that means investors and shareholders will require an increase in investment return.

Prior research found evidences that sophisticated debt holders assess off-balance sheet leases as equivalent to other debt financing (Wilkins and Zimmer, 1983; Standard \& Poor's Corporate Ratings Criteria, 2008; Altamuro et al., 2008; as cited in Han (2010)).

However, there are other mixed evidences on whether or how share market investors assess the operational lease risk. As indicated, not all users are able to take a firm theoretical position on the scientific content of the information presented in the financial statements Musvoto and Gouws (2012).

A number of previous studies provide evidences that off-balance sheet operational lease behaves like debt in the effect on equity risk and may alter the capital structure. For example, (Beattie et al., 2000a; Bowman, 1980; Ely, 1995; Imhoff Jr et al., 1993) found a positive relation between equity risk and the capitalized off-balance sheet operational lease. Aside from that, most extant findings support the value relevance of capitalized operating leases, even though, it is not clear yet whether equity investors treat the off-balance sheet leases as equivalent to those recognized in the financial statement.

Also, there were a number of studies attempting to capitalize operation lease in an ex-ante method (Beattie, Edwards, \& Goodacre, 1998; Bostwick, Fahnestock, \& O'Keefe, 2013; Branswijck, Longueville, \& Everaert, 2011; de Villiers \& Middelberg, 2013; Duke, Hsieh, \& Su, 2009; Ely, 1995; Fitó, Moya, \& Orgaz, 2013; Grossman \& Grossman, 2010; Imhoff, Lipe, \& Wright, 1991; Kilpatrick \& Wilburn, 2011; Lückerath-Rovers \& Eindhoven, 2007), and in these studies, financial ratios change measurements were based on estimations including 
lease term, the remaining lease term, discount rate and depreciation method. However the estimation can be lousy and lacking accuracy (Han, 2010).

Capitalization impact on credit risk can differ from that on equity risk, and debt holders and shareholders are most likely to perceive risk differently, and their conclusions drawn from accounting information are also different. Shareholders may have higher equity risk for the reason of hidden information; they have no legitimate access to operation lease term and interest rate. It should be noted that the off-balance sheet notes just provide information about the present value of lease obligations for the next four years, and a lump sum amount for the next years. Also, Shareholders have limited information about lease contracts provisions and their content while debt holders may enforce access to hidden information in contracts' provision text. In contrast,Altamuro, Johnston, Pandit, and Zhang (2012) claim that the effect on credit risk is more than the equity risk, given that leases represent a future cash flow commitment and can impact creditor's claims in liquidation. However, liquidation is the odd case.

Additionally,Jesswein (2008) used the Altman's discriminate analysis model and Z-score, particularly to examine the capitalization impact on individual company creditability. Meanwhile, Schneider, McCarthy, and Cotton (2012) suggested a modified copy of standard and poor's' credit rating to examine whether the operational lease amounts reported in the footnotes are significant (relevant) contributor in credit rating determination. Usually, capital consist of two sources, owners' equity and debt, both sides; owners and debt holders expected return depend on the risk margin they are taking, therefore their analysis is company specific, therefore, one of their financial analysis tools to compare and evaluate companies is the Weighted Average Cost of Capital WACC.

present study in financial risk assessment is similar to the most recent study in this area ofZhao (2013)he performed his study in the USA setting, in light of the American financial reporting Rule FR-67, the "Tabular disclosure of contractual obligations".Zhao's study focused on five types of off-balance sheet (hidden) obligations (purchase obligations, long term debt, operational lease, capital lease obligations, and other long term liabilities) and the researcher (Zhao) hypothesized that Tabular disclosures can provide additional information about company risk, and influence the assessment of credit risk by credit rating agencies, public bond holders, and private loan lenders. Zhao found that all four credit risk measures (i.e., credit ratings, negative credit watch, bond spreads, and the number of covenants in private loan contracts) significantly increase with off-balance sheet obligations when the firms report the tabular disclosures of contractual obligations for the first time. Further, Zhao's results also suggest that the three major debt-market participants view purchase obligations as at least as relevant as operating leases and other types of off-balance sheet obligations in explaining the firms' credit risk.

Lease accounting reform should stir lenders' desire to assess its effect on lessees' credibility. Similarly, it would stir credit analysts to examine capitalization impact on company creditworthiness rank, and to compare the current lease accounting standard with the proposed lease recognition rules, either a combination of financial ratios can be used in 
assessing credibility, for example, interest coverage (IC), and fixed charge coverage ratios (FCCR) that are used in the company's specific capability to generate income and cash to meet debt liabilities. Additionally, some other ratios (D/A, D/E, LTD/E) are used by creditors to assess firms' credibility. Han (2010) and most of prior researchers used leverages ratios change as an indicator of operational lease portion in cost of capital but leverage ratios change doesn't show and compare the financial structure. We use the adjusted WACC model to include the capitalized amounts of operational leases. We select Schneider et al. (2012) suggested model, which it is a modified version of standards and poor's' weighted average cost of capital, owing to the fact that it has never been practicallytested, we perform his study in the Jordanian setting, in practical study method to explore capitalized operational leases significant and relevancein credit rating.

\section{Data and Methodology}

The Weighted Average Cost of Capital (WACC) is a typical model usually used by decision makers; financial analysis, investors, and lenders to explore the firm's financial structure. The upcoming lease accounting committed lessees to capitalize all above 12 months uncancellable operation lease agreements, that means a sort of new source of capitalis added to the financial structure, capitalized amounts and the lessees incremental borrowing rate are a new determinant factors added to the equation,the approaching regulations treat leases similar to normal conventional debt with only two deference's, the interest rates, and residual value terms. Therefore, in order to examine the new regulations impact on cost of capital, we apply this regulation to the RJ financial statements of the previous 13 years(2002-2014). Then we compare the results before applying this regulation and after.

Table 1 reports the descriptive data of 30 actual aircraft operation leases.Capitalization process started with computing the amounts of unrecorded liabilities which its exactly the monthly lease payments present value, we use exact lease payments at the beginning of the month, lease term measured in months, present value computed at individual lease contract commencing date base on its exact interest rate. the unrecorded Lease liability is amortized over lease term, and lease asset is either depreciated in a straight line method over lease term, we avoid depreciating leased assets over its useful life because the upcoming lease regulations allow asset depreciation over its useful life only if the useful life of the underlying asset if shorter than lease term, in our case the minimum Aircraft useful life is about 20 years and maximum lease agreement term is 12 years. 
Table 1.The descriptive data of 30 actual aircraft operation leases

\begin{tabular}{|c|c|c|c|c|c|c|c|c|c|}
\hline & A/C type & Qty & & end-date & L.Term & $\begin{array}{l}\text { Monthly. } \\
\text { rent }\end{array}$ & $\begin{array}{l}\text { Yearly } \\
\text { rent }\end{array}$ & total rent & $\begin{array}{l}\text { pv of future } \\
\text { payments }\end{array}$ \\
\hline 1 & A-340-212 & 1 & 2002-07-18 & $2014-12-31$ & 150 & 270,000 & 3240000 & 40380164 & 30383546 \\
\hline 2 & A-340-212 & 1 & 2002-08-09 & $2014-12-31$ & 149 & 270,000 & 3240000 & 40184877 & 30049311 \\
\hline 3 & A-340-212 & 1 & $2003-05-29$ & $2014-12-31$ & 139 & 244,242 & 2930904 & 33998486 & 25837738 \\
\hline 4 & A-340-212 & 1 & $2003-07-29$ & $2014-12-31$ & 137 & 244,240 & 2930880 & 33508390 & 25561740 \\
\hline 5 & A-319-132 & 1 & $2008-03-13$ & $2018-03-13$ & 9335 & 184,310 & 2211720 & 1720596970 & 17449097 \\
\hline 6 & A-319-132 & 1 & $2008-10-30$ & $2018-10-30$ & 120 & 324,175 & 3890100 & 38922316 & 30690416 \\
\hline 7 & A-319-132 & 1 & $2009-02-20$ & $2019-02-20$ & 120 & 354,846 & 4258152 & 42604852 & 33594178 \\
\hline 8 & A-319-132 & 1 & 2009-03-14 & 2019-03-14 & 120 & 359,490 & 4313880 & 43162438 & 34033827 \\
\hline 9 & A $320-232$ & 1 & 2006-11-17 & 2018-11-17 & 144 & 209,233 & 2510796 & 30150189 & 22716255 \\
\hline 10 & A $320-232$ & 1 & 2011-04-29 & 2019-04-29 & 96 & 230,513 & 2766156 & 22144405 & 18283704 \\
\hline 11 & A320-232 & 1 & 2011-09-21 & $2017-09-21$ & 72 & 283,088 & 283,088 & 20400944 & 17591280 \\
\hline 12 & A $320-232$ & 1 & 2011-10-19 & $2019-10-19$ & 96 & 232,000 & 2784000 & 22287255 & 18399886 \\
\hline 13 & A320-232 & 1 & $2012-05-24$ & $2018-05-24$ & 72 & 284050 & 3408600 & 20460939 & 17746451 \\
\hline 14 & A320-232 & 1 & $2012-11-20$ & $2018-11-20$ & 72 & 288,700 & 3464400 & 20795892 & 18041551 \\
\hline 15 & A321-231 & 1 & 2008-04-09 & 2014-04-09 & 72 & 479,781 & 5757372 & 34560006 & 29914729 \\
\hline 16 & A321-231 & 1 & $2008-05-20$ & $2014-05-20$ & 72 & 482,940 & 5795280 & 34787557 & 30796624 \\
\hline 17 & A321-231 & 1 & 2012-04-16 & $2020-04-16$ & 96 & 364850 & 4378200 & 35049590 & 30076718 \\
\hline 18 & A321-231 & 1 & 2012-06-15 & $2020-06-15$ & 96 & 365690 & 4388280 & 35130285 & 29005230 \\
\hline 19 & EMJ195 & 1 & 2006-11-30 & 2014-11-30 & 96 & 230122 & 2761464 & 22106843 & 18387901 \\
\hline 20 & EMJ195 & 1 & $2007-02-03$ & $2015-02-03$ & 96 & 281409.5 & 3376914 & 27033816 & 22288196 \\
\hline 21 & EMJ195 & 1 & 2007-07-01 & 2015-07-01 & 96 & 240820 & 2889840 & 23134555 & 19242725 \\
\hline 22 & EMJ175 & 1 & 2010-11-11 & 2018-11-11 & 96 & 231700 & 2780400 & 22258435 & 18514298 \\
\hline 23 & A330-223 & 1 & $2010-05-21$ & $2014-12-31$ & 55 & 601466 & 7217592 & 33319569 & 29760179 \\
\hline 24 & A330-223 & 1 & $2010-05-21$ & $2015-01-31$ & 56 & 601570 & 7218840 & 33938437 & 30248391 \\
\hline 25 & A330-223 & 1 & 2011-08-01 & $2017-01-31$ & 66 & 663,072 & 7956858 & 43817218 & 38549055 \\
\hline 26 & B787-BAA & 1 & 2014-08-27 & $2026-08-26$ & 144 & 837,380 & 10048560 & 120637781 & 90913697 \\
\hline 27 & B787-BAB & 1 & 2014-09-30 & 2026-09-30 & 144 & 954,500 & 11454000 & 137542142 & 103629391 \\
\hline 28 & B787-BAF & 1 & 2014-10-01 & 2026-10-01 & 144 & 954,500 & 11454000 & 137542142 & 103629391 \\
\hline 29 & B787-BAC & 1 & 2014-11-19 & 2026-11-19 & 144 & 991,368 & 11896410 & 142854699 & 107631779 \\
\hline 30 & B787-BAE & 1 & 2014-11-20 & 2026-11-20 & 144 & 973,430 & 11681160 & 140269930 & 105684672 \\
\hline
\end{tabular}

WACC $=($ weight of equity*cost of equity + Weight of debt $*$ cost of debt $))$

$\mathrm{WACC}=r_{E} \times\left(\frac{E}{E+D}\right)+r_{D} \times(1-t) \times\left(\frac{D}{E+D}\right)$

Operation lease capitalization results in a different capital structure. The company's capital consists of debt, recorded financial lease, owners' equity, plus the capitalized amount of operation lease. So, to guarantee more accuracy we adjust the unrecorded lease liabilities by the recorded short term lease liabilities, the unrecorded owners' equity either adjusted by the tax savings. Thus, the adjusted WACCconsists of three parts, equity, debt, and the capitalized 


\section{Macrothink}

operation lease (unrecorded liabilities) as follow:

$$
\text { adj. WACC }=r_{E} \times\left(\frac{E}{E+D+F L}\right)+r_{D} \times(1-t) \times\left(\frac{D}{E+D+F L}\right)+r_{F L} \times(1-t) \times\left(\frac{C O L}{E+D+C O L}\right)
$$

Where: $r_{F L}$ is the lessee's incremental borrowing rate, it differs overs the past 13 years it, range between (4\%-5\%). In our computations we select a more conservative approach, thus, we use the highest rate $(5 \%)$. For the purpose of equity rate of return (re) computation we use the capital asset pricing model (CAPM). Cost of Equity $=$ Risk Free rate $+($ company Beta $\times$ Market Risk Premium). We compute the average interest rate on Jordan government treasury bonds over the period (2010-2015), bonds information retrieved from Amman Stock Exchange web site (www.ase.com.jo/bonds_table/all). Risk free rate average 5.5\%. we either use the international airfreight sector mean Beta as a company Beta, Lee and Hooy (2012) investigated a sample of 462 companies of the airlines sector in North America, Europe and ASIA, their study results an airfreight sector Beta mean of (0.77). Also we compensate Moodys' computed Total Equity Premium for the Market Risk Premium. Moodys' Ratings is a trusted international financial and economical rating agency. Return on equity (re $)=5.5 \%+(0.77 *$ $(12.5 \%-5.5 \%))=10.89 \%$.For the purpose of owners' equity $(\mathrm{E})$ computation we use the average yearly market price multiplied by the average shares issued as follow: $\mathrm{E}=$ Shares Market Price * Shares Issued. (After tax Return) on debit computed as follow: $R d=$ $(1-$ Tax Rate $) *$ interest rate ....(3). we select Interest rate in a conservative approach; $(0.022 \%)$ is the least annual interest, local lenders charge the Royal Jordanian Airlines in 2013. $R d=(1-0.20) * 0.022=0.018$. Table 2 reports a comparison between WACC and the after capitalization Adjusted WACC. 


\section{Macrothink}

Asian Journal of Finance \& Accounting

ISSN 1946-052X

2015, Vol. 7, No. 2

Table 2. Comparison of WACC before and after operation lease capitalization over 13 years

\begin{tabular}{|c|c|c|c|c|c|c|c|c|c|c|c|c|c|}
\hline Tax: $t$ & Beta & total equity risk & risk free & Return on equity & $(1-\mathrm{T})$ & return on debt & return on lease & & $\mathrm{Rd}$ & & & & \\
\hline 0.200 & 0.770 & 12.5 & 5.5 & 10.89 & 0.8 & 0.022 & 0.050 & & 0.0176 & & & & \\
\hline recorded owners' equity & 2002 & 2003 & 2004 & 2005 & 2006 & 2007 & 2008 & 2009 & 2010 & 2011 & 2012 & 2013 & 2014 \\
\hline ROE & 35432000 & 29622000 & 58892000 & 82600000 & 88735000 & 109098000 & 85736000 & 106591000 & 116246000 & 58124000 & 59424000 & 19566000 & -15855000 \\
\hline TD (Total Debt) & 91176000 & 70011000 & 69724000 & 58560000 & 48773000 & 55680000 & 75435000 & 79552000 & 72861000 & 97362000 & 142556000 & 198195000 & 148120000 \\
\hline TOTAL & 126608000 & 99633000 & 128616000 & 141160000 & 137508000 & 164778000 & 161171000 & 186143000 & 189107000 & 155486000 & 201980000 & 217761000 & 132265000 \\
\hline $\mathbf{D} /(\mathbf{D}+\mathbf{E})$ & $72.01 \%$ & $70.27 \%$ & $54.21 \%$ & $41.48 \%$ & $35.47 \%$ & $33.79 \%$ & $46.80 \%$ & $42.74 \%$ & $38.53 \%$ & $62.62 \%$ & $70.58 \%$ & $91.01 \%$ & $111.99 \%$ \\
\hline \multirow[t]{2}{*}{$\mathbf{E} /(\mathbf{D}+\mathbf{E})$} & $27.99 \%$ & $29.73 \%$ & $45.79 \%$ & $58.52 \%$ & $64.53 \%$ & $66.21 \%$ & $53.20 \%$ & $57.26 \%$ & $61.47 \%$ & $37.38 \%$ & $29.42 \%$ & $8.99 \%$ & $-11.99 \%$ \\
\hline & 2002 & 2003 & 2004 & 2005 & 2006 & 2007 & 2008 & 2009 & 2010 & 2011 & 2012 & 2013 & 2014 \\
\hline ADJ.TD (Total Debt) & 72495000 & 29273000 & 61556000 & 50103000 & 40631000 & 53295000 & 70617000 & 74421000 & 67397000 & 91543000 & 136366000 & 191650000 & 141092000 \\
\hline АOEB & 53692000 & 68122370 & 62752643 & 85175819 & 89882245 & 102196045 & 79025919 & 96036980 & 103120422 & 43203399 & 43866124 & 5898008 & -24962643 \\
\hline net URL (COL) & 58621992 & 104550269 & 97283347 & 89316606 & 121499086 & 148037524 & 234643813 & 267065022 & 299582100 & 332665231 & 352774154 & 267659065 & 685448704 \\
\hline total & 184808992 & 201945639 & 221591990 & 224595425 & 252012331 & 303528569 & 384286731 & 437523002 & 470099522 & 467411629 & 533006278 & 465207073 & 801578061 \\
\hline ad.D/(D+E+COL) & 0.392 & 0.145 & 0.278 & 0.223 & 0.161 & 0.176 & 0.184 & 0.170 & 0.143 & 0.196 & 0.256 & 0.412 & 0.176 \\
\hline ad.E/(D+E+COL) & 0.291 & 0.337 & 0.283 & 0.379 & 0.357 & 0.337 & 0.206 & 0.220 & 0.219 & 0.092 & 0.082 & 0.013 & -0.031 \\
\hline URL(COL)/E+D+COL) & 0.317 & 0.518 & 0.439 & 0.398 & 0.482 & 0.488 & 0.611 & 0.610 & 0.637 & 0.712 & 0.662 & 0.575 & 0.855 \\
\hline \multirow[t]{2}{*}{ change in total debt } & $31 \%$ & $51 \%$ & $42 \%$ & $37 \%$ & $45 \%$ & $46 \%$ & $58 \%$ & $57 \%$ & $60 \%$ & $67 \%$ & $62 \%$ & $53 \%$ & $83 \%$ \\
\hline & 2002 & 2003 & 2004 & 2005 & 2006 & 2007 & 2008 & 2009 & 2010 & 2011 & 2012 & 2013 & 2014 \\
\hline$(E /(E+D)) * r e$ & 3.048 & 3.238 & 4.986 & 6.372 & 7.027 & 7.210 & 5.793 & 6.236 & 6.694 & 4.071 & 3.204 & 0.978 & -1.305 \\
\hline$r d^{*}(1-t)$ & 0.018 & 0.018 & 0.018 & 0.018 & 0.018 & 0.018 & 0.018 & 0.018 & 0.018 & 0.018 & 0.018 & 0.018 & 0.018 \\
\hline$D /(E+D) * r d^{*}(1-t)$ & 0.013 & 0.012 & 0.010 & 0.007 & 0.006 & 0.006 & 0.008 & 0.008 & 0.007 & 0.011 & 0.012 & 0.016 & 0.020 \\
\hline WACC & 3.060 & 3.250 & 4.996 & 6.380 & 7.034 & 7.216 & 5.801 & 6.243 & 6.701 & 4.082 & 3.216 & 0.994 & -1.286 \\
\hline$(E /(E+D+C O L)) * r e$ & 3.164 & 3.674 & 3.084 & 4.130 & 3.884 & 3.667 & 2.239 & 2.390 & 2.389 & 1.007 & 0.896 & 0.138 & -0.339 \\
\hline$r d^{*}(1-t)$ & 0.018 & 0.018 & 0.018 & 0.018 & 0.018 & 0.018 & 0.018 & 0.018 & 0.018 & 0.018 & 0.018 & 0.018 & 0.018 \\
\hline$(\mathrm{D} /(\mathbf{E}+\mathrm{D}+\mathrm{COL}))^{*} \mathrm{rd}^{*}(\mathbf{1}-\mathrm{t})$ & 0.007 & 0.003 & 0.005 & 0.004 & 0.003 & 0.003 & 0.003 & 0.003 & 0.003 & 0.003 & 0.005 & 0.007 & 0.003 \\
\hline$\left(\mathbf{r l}^{*}(1-t)\right.$ & 0.040 & 0.040 & 0.040 & 0.040 & 0.040 & 0.040 & 0.040 & 0.040 & 0.040 & 0.040 & 0.040 & 0.040 & 0.040 \\
\hline$(\mathrm{L} /(\mathrm{E}+\mathrm{D}+\mathrm{COL}))^{*} \mathbf{r l}^{*}(1-\mathrm{t})$ & 0.013 & 0.021 & 0.018 & 0.016 & 0.019 & 0.020 & 0.024 & 0.024 & 0.025 & 0.028 & 0.026 & 0.023 & 0.034 \\
\hline ad.WACC & 3.183 & 3.697 & 3.106 & 4.150 & 3.906 & 3.689 & 2.267 & 2.418 & 2.417 & 1.038 & 0.927 & 0.168 & -0.302 \\
\hline Adj.WACC- WACC & 0.123 & 0.447 & -1.890 & -2.230 & -3.128 & -3.527 & -3.534 & -3.826 & -4.284 & 0.032 & 0.031 & 0.030 & 0.037 \\
\hline
\end{tabular}

\section{Results}

Figure 1 show RJ capital structure over the period 2002-2014. Equity percentage exceed debt percentage during (2004-2010), this is related to share prices improvement, the period (2010-2014)shows increase in debt percentage and at the same time a decrease in share prices, share prices escalating decrease because of the international financial crises consequences, either related to the negative financial results. Table 2 reveal that owners' equity before capitalization shows higher portion over (2005-2010), either Figure 2 shows highest WACC before capitalization for the same period (2005-2010), our computations is based on (10.89\%) return on equity which it is either higher than $0.022 \%$ return on debt is also another reason for this result. 


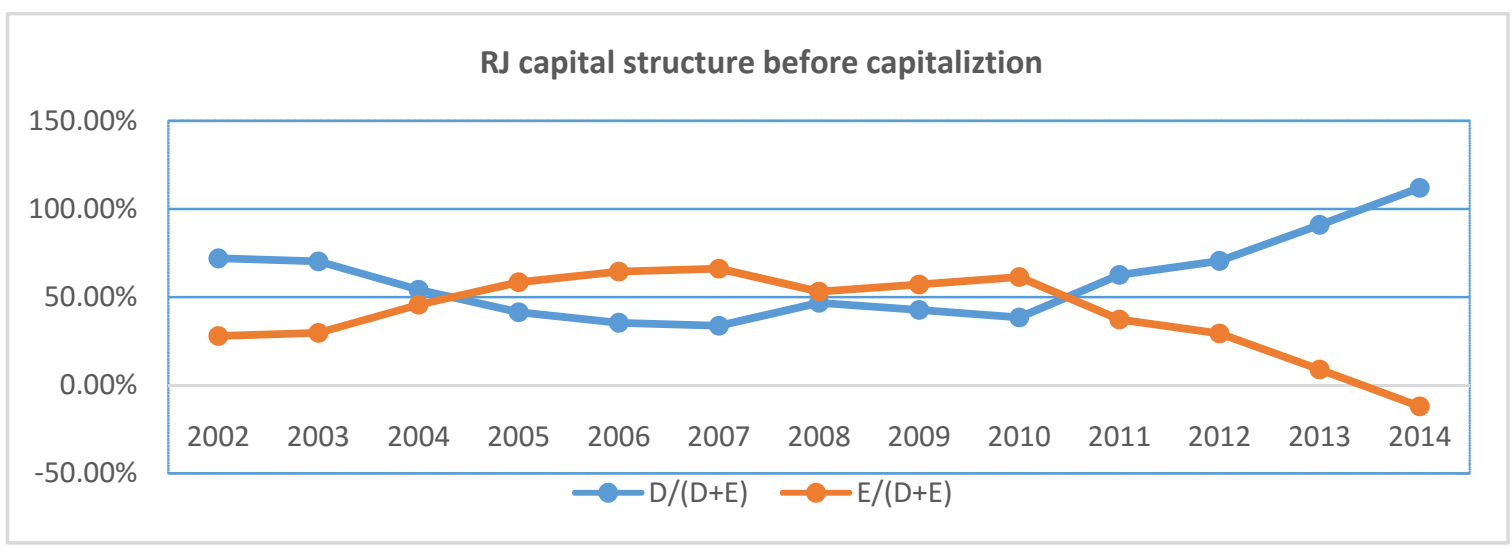

Figure 1.Capital structure before capitalization

Table 3 reports the unrecorded lease assets, liabilities and owners' equity. Capitalization process resulted in an increase on lease liabilities, this result is consistent with (Beattie et al., 2000a, 2000b; Ely, 1995); Imhoff Jr et al. (1993), increase in liability resulted in an increase in total debt, they reported $40 \%$ total debt increase, our results reveal with $(31 \%-83 \%)$ increase in total debt over the period (2002-2014). Table 3 either reports a negative impact in equity, this result monopolize the RJ capital structure.

Table 3. The capitalized (unrecorded) assets, liabilities and owners' equity

\begin{tabular}{rrrrr}
\hline 2002 & & & & \multicolumn{1}{l}{ UROE } \\
2003 & 2 & 58551825 & 58200992 & -350833 \\
2004 & 4 & 104235803 & 102312639 & -1923164 \\
2005 & 4 & 96885982 & 92975990 & -3909992 \\
2006 & 6 & 121443518 & 114708247 & -6735271 \\
2007 & 8 & 147809282 & 138954486 & -8854797 \\
2008 & 12 & 234403305 & 223319648 & -11083658 \\
2009 & 14 & 266298221 & 251380002 & -14918219 \\
2010 & 17 & 298970207 & 280992522 & -17977685 \\
2011 & 20 & 332204911 & 311925629 & -20279282 \\
2012 & 25 & 352529389 & 331026278 & -21503110 \\
2013 & 25 & 267874085 & 247446073 & -20428012 \\
2014 & 22 & 686164099 & 669313061 & -16851038 \\
\hline
\end{tabular}

Figure 2 shows the after capitalization capital structure.Capitalization of all RJ operational lease agreements resulted in a positive change in the Royal Jordanian Airlines ad.WACC. Figure 2 reports a comparison between WACC and the after capitalization adj.WACC. our results seems consistent with Jesswein (2008) results, he reported $20 \%$ after operation lease capitalization drop in Z-score credit rating model. 


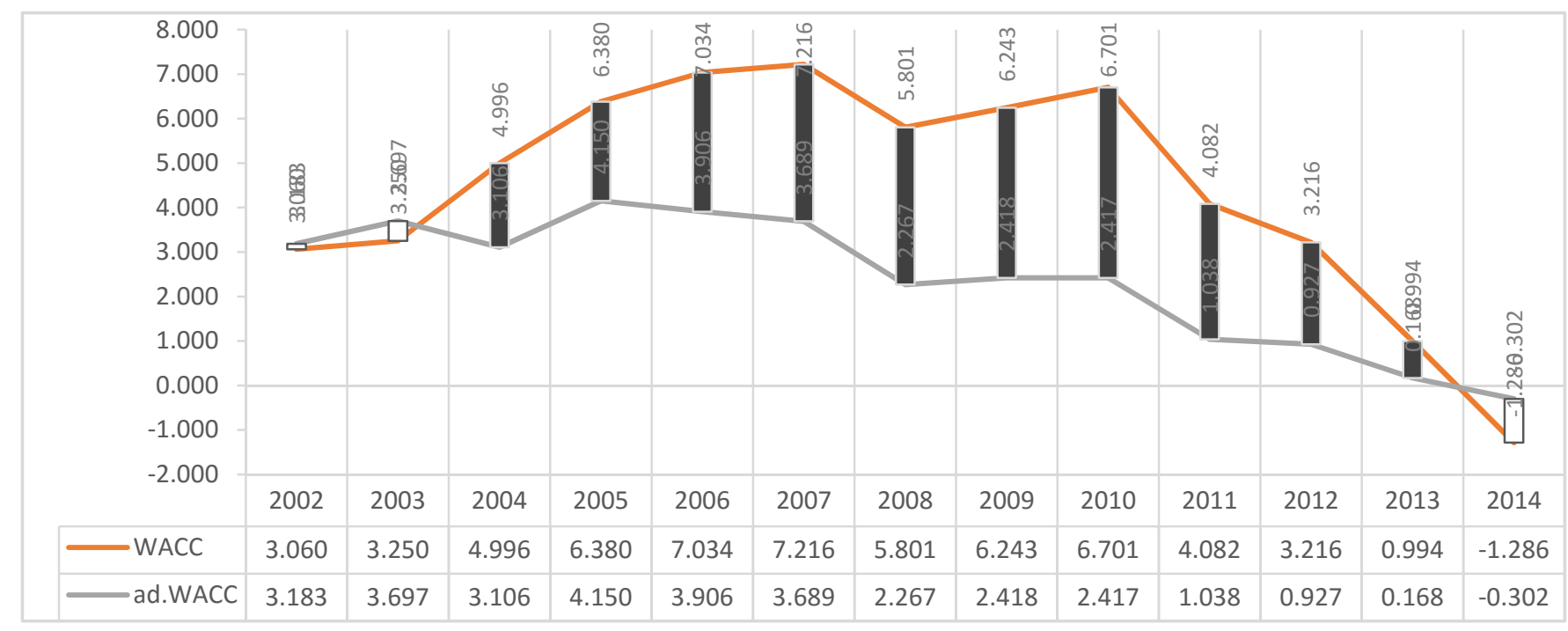

Figure 2. WACC before capitalization and ad.WACC after capitalization

Figure 3 shows that this positive change in WACC is due to three reasons; 1) capital structure change, capitalized operation lease (COL) percentage increased from $31 \%$ in 2002 to $85 \%$ in 2014. 2) This is accompanied by a decreasing percentage of debt compared to total capital 3 ) the negative impact on owners' equity resulted from operation lease capitalization. The year 2014 shows a negative owner equity percentage due to the fact that losses exceeds its recorded equity.

The positive change in WACC as credit rating measurement tool is consistent with Zhao (2013) results, he hypothesized that "Tabular disclosures" can provide additional information about company risk, and influence the assessment of credit risk by credit rating agencies, public bond holders, and private loan lenders, we either provide additional practical evidences on the upcoming lease accounting regulations usefulness, applying these regulations to firmsrelay heavily on long term operation lease resulted in a positive change in RJ credit rating, even with $5 \%$ financial lease interest, which its higher than $.022 \%$ return on debt and with $10.89 \%$ return on equity. 


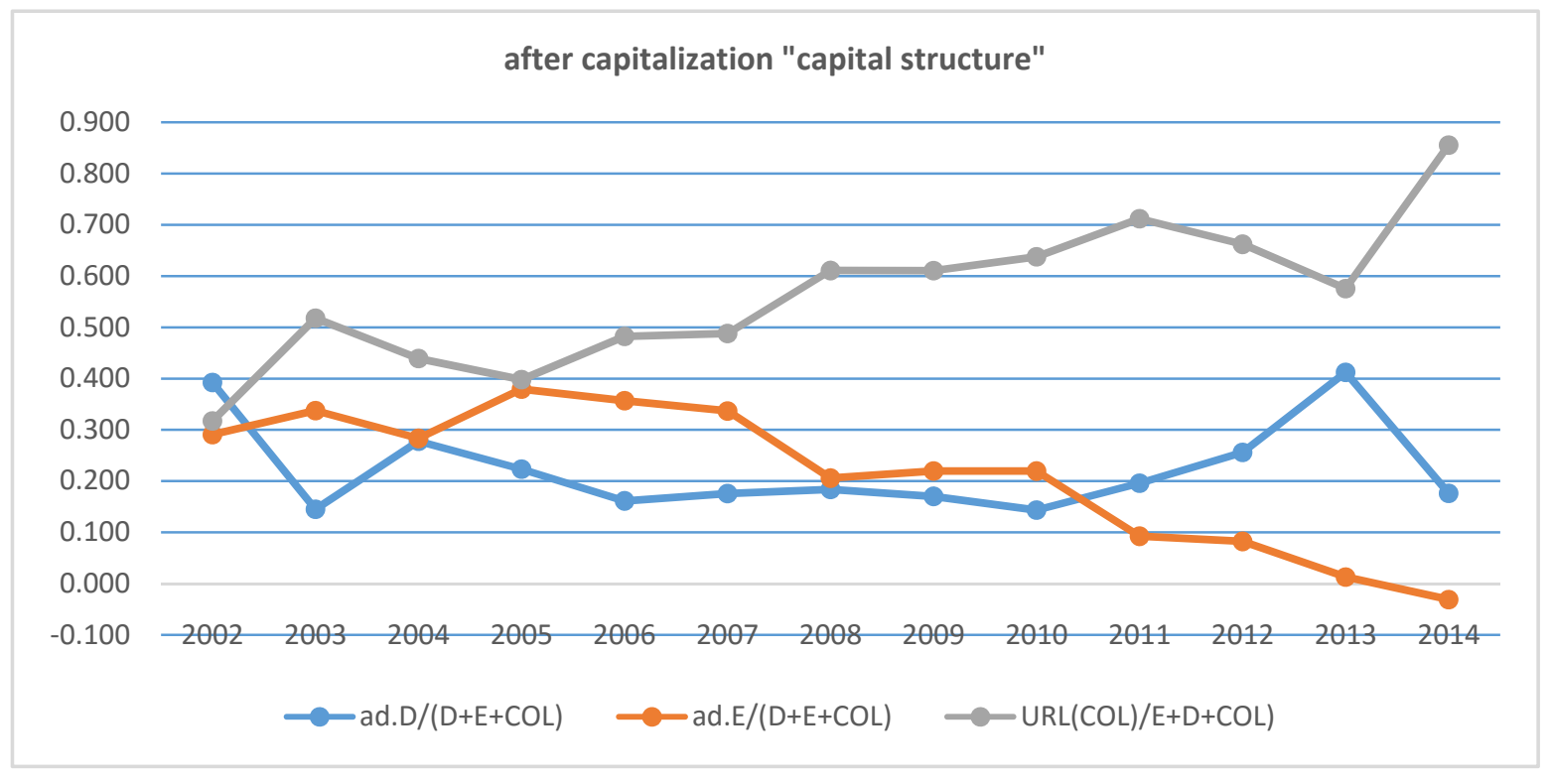

Figure 3.Capital structure after capitalization

\section{Conclusion}

In light of thelease accounting reform upcoming regulations, we have reviewed some of possible impacts of operation lease capitalization on capital structure, financial risk, equity risk, and cost of capital measurement. Taking in account the credit rating crucial role in investors and lenders credit providing,providing evidence lease accounting reform is an issue since the sixties of last century, many of these attempts have been insufficient owing to the fact of hidden information about operation lease activities. Due to the nature of data and information we have used, we believe that we have provided a practically accurate evidence on some of operation lease capitalization economic consequences, particularly on capital structure and WACC which it is being used in credit rating.

Results indicate that operation lease capitalization has a positive impact on credit rating WACC, which isconsistent with the boards (IASB \&FASB) believe, investors and credit holder's right to obtain a full transparent picture about firms lease activities in benefit of all parties.

\section{Acknowledgement}

The research is financed by Jadara University, Irbid, Jordan

\section{References}

Altamuro, Jennifer Lynne M., Johnston, Rick M., Pandit, Shailendra, \& Zhang, Haiwen. (2012). Operating Leases and Credit Assessments. Rochester: Social Science Research Network.

Beattie, Vivien, Edwards, Keith, \& Goodacre, Alan. (1998). The impact of constructive operating lease capitalisation on key accounting ratios. Accounting and Business Research, 28(4), 233-254. http://dx.doi.org/10.1080/00014788.1998.9728913 
Beattie, Vivien, Goodacre, Alan, \& Thomson, Sarah. (2000a). Operating leases and the assessment of lease-debt substitutability. Journal of Banking \& Finance, 24(3), 427-470. http://dx.doi.org/10.1016/S0378-4266(99)00045-X

Beattie, Vivien, Goodacre, Alan, \& Thomson, Sarah. (2000b). Recognition versus Disclosure: An Investigation of the Impact on Equity Risk Using UK Operating Lease Disclosures. Journal of Business Finance \& Accounting, 27(9/10), 1185-1224. http://dx.doi.org/10.1111/1468-5957.00352

Bostwick, Eric D., Fahnestock, Robert T., \& O'Keefe, W. Timothy. (2013). Effects of lease capitalization techniques on key measures of financial performance. Journal of Finance \& Accountancy, 12, 91-102.

Bowman, Robert G. (1980). The Debt Equivalence of Leases: An Empirical Investigation. Accounting Review, 55(2), 237.

Branswijck, Deborah, Longueville, Stefanie, \& Everaert, Patricia. (2011). THE FINANCIAL IMPACT OF THE PROPOSED AMENDMENTS TO IAS 17: EVIDENCE FROM BELGIUM AND THE NETHERLANDS. Accounting \& Management Information Systems / Contabilitate si Informatica de Gestiune, 10(2), 275-294.

de Villiers, Rikus R., \& Middelberg, Sanlie L. (2013). Determining The Impact Of Capitalising Long-Term Operating Leases On The Financial Ratios Of The Top 40 JSE-Listed Companies. The International Business \& Economics Research Journal (Online), 12(6), 655.

Duke, J. C., Hsieh, S. J., \& Su, Y. (2009). Operating and synthetic leases: Exploiting financial benefits in the post-Enron era. Advances in Accounting, 25(1), 28-39. http://dx.doi.org/10.1016/j.adiac.2009.03.001

Ely, Kirsten M. (1995). Operating lease accounting and the market's assessment of equity risk. Journal of Accounting Research, 33(2), 397. http://dx.doi.org/10.2307/2491495

Fitó, M. Àngels, Moya, Soledad, \& Orgaz, Neus. (2013). Considering the effects of operating lease capitalization on key financial ratios*/Consideración de los efectos de la capitalización de arrendamientos operativos en las principales ratios financieras. Revista Española de $\begin{array}{llll}\text { Financiación } & y & \text { Contabilidad, } & \text { 42(159), }\end{array}$ http://dx.doi.org/10.1080/02102412.2013.10779750

Grossman, Amanda M., \& Grossman, Steven D. (2010). Capitalizing Lease Payments. CPA Journal, 80(5), 6-11.

Han, F. . (2010). Lease accounting and the cost of equity capital. (phd), University of Connecticut. Retrieved from http://ezproxy.usim.edu.my:2102/docview/882902624/14103B84CD128596A82/1?accountid $=33993$ Available from proquest

Heffes, Ellen M. (2013). FASB, IASB RELEASE EXPOSURE DRAFT ON LEASE ACCOUNTING. Financial Executive, 29(5), 7-8.

Imhoff, Eugene A., Jr., Lipe, Robert C., \& Wright, David W. (1991). Operating Leases: Impact of Constructive Capitalization. Accounting Horizons, 5(1), 51.

Imhoff Jr, Eugene A., Lipe, Robert, \& Wright, David W. (1993). The Effects of Recongition 
Versus Disclosure on Shareholder Risk and Executive Compensation. Journal of Accounting, Auditing \& Finance, 8(4), 335-368.

Jesswein, Kurt R. (2008). METHODOLOGICAL ISSUES IN ANALYZING FINANCIAL STATEMENTS IN THE PRESENCE OF OPERATING LEASES. Allied Academies International Conference: Proceedings of the Academy of Accounting \& Financial Studies (AAFS), 13(1), 27-32.

Kilpatrick, Bob G., \& Wilburn, Nancy L. (2011). Convergence On A Global Accounting Standard For Leases - Impacts Of The FASB/IASB Project On Lessee Financial Statements. The International Business \& Economics Research Journal, 10(10), 55-59.

Lee, Chyn-Hwa, \& Hooy, Chee-Wooi. (2012). Determinants of systematic financial risk exposures of airlines in North America, Europe and Asia. Journal of Air Transport Management, 24, 31-35. http://dx.doi.org/10.1016/j.jairtraman.2012.06.003

Lückerath-Rovers, Mijntje, \& Eindhoven, geboren te. (2007). OPERATING-LEASE DISCLOSURESAn empirical investigation. (phd).

Musvoto, S. Wedzerai, \& Gouws, Daan G. (2012). Towards Formulating An Accounting Theory Of Meaningfulness. Journal of Applied Business Research, 28(5), 825-835.

Schneider, Douglas K., McCarthy, Mark G., \& Cotton, Brett. (2012). A METHODOLOGICAL FRAMEWORK FOR EXAMINING INFORMATION CONTENT OF PROPOSED LEASE ACCOUNTING RULE. Journal of Theoretical Accounting Research, 8(1), 113-127.

Zhao, Sha. (2013). Credit risk and off-balance-sheet contractual obligations: Disclosures under Rule FR-67. (3589788), City University of New York, Ann Arbor. Retrieved from http://search.proquest.com/docview/1430900274? accountid=33993 